Barbara Kobzarska-Bar

ORCID: 0000-0003-0559-2220

Wyższa Szkoła Handlowa we Wrocławiu

Anna Arcinowska

Filip Janczak

Weronika Marchwińska

\title{
Zarządzanie wizerunkiem osoby publicznej - autokreacja Roberta Biedronia podczas kampanii na prezydenta miasta w 2014 roku
}

DOI: $10.19195 / 1643-0328.26 .6$

Słowa kluczowe: zarządzanie wizerunkiem osobistym, marketing polityczny, kampania wyborcza, media społecznościowe

\section{Wstęp}

Celem badania wypowiedzi Roberta Biedronia pochodzących z okresu, w którym ubiegał się o stanowisko prezydenta miasta Słupsk w 2014 roku, było ustalenie zachowań językowych kandydata istotnych dla jego publicznego wizerunku. Tworzą one jego image świadomie kreowany na potrzeby kampanii prezydenckiej. Zbudowanie wizerunku kandydata zgodnego z oczekiwaniami wyborców jest jednym z najważniejszych zadań marketingu politycznego na poziomie lokalnym. Znaczenie tej kwestii podkreślają autorzy zajmujący się tematyką marketingu politycznego, między innymi Agnieszka Szczudlińska-Kanoś, według której „utrata dobrego image (nawet najdrobniejsze potknięcie) w zasadzie wyklucza z walki wyborczej"'.

1 A. Szczudlińska-Kanoś, Marketing polityczny w polskim samorządzie regionalnym, „Studia Regionalne i Lokalne" 2009, nr 3, s. 113. 


\section{Metodologia badania}

Badanie autowizerunku Roberta Biedronia ograniczono do analizy jego zachowań językowych pochodzących wyłącznie z czasu, gdy kandydował na prezydenta miasta Słupska. Zwykle badanie kreowanego na potrzeby kampanii wyborczej wizerunku kandydata jest wieloaspektowe, obejmuje między innymi analizę komunikacji niewerbalnej, kontekstu wypowiedzi itp. i przeprowadza się je na bogatym materiale źródłowym, oraz analizuje się wystąpienia $\mathrm{z}$ wielu lat. Trafność wniosków zwiększa się przez triangulację, zbierając dane pochodzące z licznych źródeł za pomocą różnych technik badawczych, na przykład obserwacji czy sondażu.

W prezentowanym badaniu analizie poddano jedynie zachowania językowe kandydata i tylko te ujawnione $\mathrm{w}$ wypowiedziach, które zostały opublikowane $\mathrm{w}$ serwisie YouTube w okresie od 2 września do 30 listopada 2014 roku. Nie zbadano środków komunikacji niewerbalnej (na przykład gestykulacji) i jej własności, takich jak siła i dynamika przekazu. Pominięto ponadto kontekst wypowiedzi (miejsce, przestrzeń i czas zdarzeń, czynniki strukturalne) czy też strategie i taktyki działania, takie jak zabiegi marketingowe ukierunkowane na zwiększenie liczby „wejść na wizję" kandydata. Tych aspektów w prezentowanej analizie nie poddano badaniu, mając na uwadze, że realizacja takiego zamierzenia, chociaż zgodna z postulatem Anzelma Straussa ${ }^{2}$, wymagałaby zastosowania znacznie bardziej rozbudowanego spektrum narzędzi badawczych. Tymczasem autorzy badania skupili uwagę na procesie budowania znaczeń poprzez zachowania językowe, a ich celem było odkrycie intencji wypowiedzi, czyli znaczenia, jakie nabiera ona oddzielona od innych elementów przekazu. Intencja wypowiedzi nie musi być bowiem identyczna $\mathrm{z}$ intencją czytelnika. Nie musi być również tożsama z intencją autora. Intencję dzieła należy utożsamiać raczej ze strategią, ,jaka została zawarta w tekście dla prowadzenia czytelnika modelowego ku określonym, nie dowolnym, interpretacjom"3.

Założenie, że przedmiotem badania jest intencja wypowiedzi i co za tym idzie - podjęcie decyzji o wyborze do badania tylko jednego środka komunikacji (języka) oraz czasowe ograniczenie analizy przyniosło określone skutki. Na podstawie przedstawionego badania nie można udzielić odpowiedzi na pytanie, czy wykreowany wizerunek jest spójny z rzeczywistą tożsamością Roberta Biedronia, a także nie można wyciągać wniosków dotyczących realizacji prezentowanej przez kandydata wizji zmiany i rozwoju Słupska już jako prezydenta tego miasta. Można natomiast wyróżnić kategorie charakterystyczne dla autowizerunku Roberta Biedronia i określić ich własności. Właśnie te wyeksponowane przez kandydata elementy autowizerunku i oferty wyborczej musiały być zgodne z oczekiwaniami mieszkańców Słupska, skoro oddali na niego głosy. Prawdziwość tej hipotezy należałoby jednak zweryfikować na przykład w badaniach ankietowych, gdyż o sukcesie Roberta Biedronia w wyborach mogły zadecydować również inne czynniki. Prawdziwość hipotezy można byłoby ponadto sprawdzić, przeprowadzając podczas kolejnych wyborów samorządowych w 2018 roku badanie podobne do prezentowanego.

\footnotetext{
2 A.L. Strauss, Qualitative Analysis for Social Scientists, Cambridge 1987, s. 27.

${ }^{3}$ Ibidem, s. 153.
} 
Analizę oparto na paradygmacie interpretatywnym, zgodnie z którym „rzeczywistość społeczna nie ma charakteru konkretnego, lecz jest tworem intersubiektywnym uczestników, czyli ludzi, którzy sami, poprzez swoje działania, tworzą ją wciąż na no-

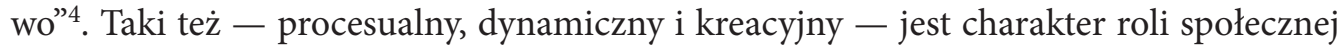
aktora politycznego. Powstaje ona w procesie nadawania znaczeń i ich negocjacji. W wypadku kandydata starającego się o fotel prezydenta miasta wiąże się to z odnajdowaniem lub kreowaniem przekonań wspólnych z wyborcami i motywowaniem tych ostatnich do udzielenia właściwego poparcia ${ }^{5}$.

Wraz z paradygmatem interpretatywnym przyjęto właściwe dla niego techniki zbierania danych. Zastosowanie technik jakościowych umożliwiło uchwycenie znaczeń nadawanych światu przez podmiot badania. Wyodrębniono w ten sposób kategorie i ich własności, które są znaczące dla badanej jednostki. Do dalszych analiz wybrano kategorie reprezentowane przez największą liczbę powtórzeń znaków językowych. Zastosowanie reguły większości, charakterystycznej dla zwolenników paradygmatu normatywnego, którzy pragną odkryć zjawisko dominujące, jest uzasadnione w badanym przypadku dążeniem do „zdiagnozowania, czy określone dane empiryczne mają jakieś znaczenie dla jednostki, czy też nie”6.

Użycie w jednym badaniu technik ilościowych i jakościowych nie oznacza, że zastosowano różne paradygmaty badawcze. Krzysztof Konecki zauważa „Nie można przypisać technik i danych jakościowych do jednego paradygmatu, ilościowych zaś do innego" ${ }^{\prime}$. Można natomiast przyjąć, że te dwa sposoby zbierania danych według klucza i l oś ć versus k a t e g o r i a (pojęcie) uzupełniają się. Jak odnotowuje Konecki „Kategorie zwykle porządkują logicznie opisaną przez badacza rzeczywistość", natomiast ilości „porządkują statystycznie według reguły większości już wcześniej skategoryzowaną rzeczywistość społeczną"

Postępując zgodnie z wcześniej poczynionymi założeniami dotyczącymi zastosowania technik jakościowych i ilościowych w jednym badaniu, odwołano się do propozycji konstruowania teorii na podstawie systematycznie zbieranych danych empirycznych, czyli do metodologii teorii ugruntowanej w wersji przedstawionej przez Koneckiego ${ }^{9}$. Propozycji teoretycznej nie budowano tutaj zatem, opierając się na wcześniej przyjętych aksjomatach. Wyróżnienie kategorii (i ich własności) pozwoliło na odkrycie powiązań między nimi, które stały się hipotezami w tym sensie, że są one twierdzeniami wskazującymi na relacje pomiędzy pojęciami. „Hipoteza w tradycyjnym sensie wymaga pomiaru siły związku pomiędzy zmiennymi, które mogą być skonceptualizowane. W metodologii teorii ugruntowanej nie chodzi o pomiar, a o ugruntowane empirycznie wskazanie na istnienie relacji pomiędzy pojęciami” 10 - podkreśla Konecki.

\footnotetext{
${ }^{4}$ M. Kostera, Antropologia organizacji. Metodologia badań terenowych, Warszawa 2005, s. 16.

${ }^{5}$ K. Konecki, Studia z metodologii badań jakościowych. Teoria ugruntowana, Warszawa 2000, s. 17.

${ }^{6}$ Ibidem, s. 19.

7 Ibidem, s. 20.

8 Ibidem.

9 Ibidem.

10 Ibidem, s. 30.
} 
Operacjonalizując problem badawczy, odwołano się do definicji wizerunku sformułowanej przez Wojciecha Cwalinę i Andrzeja Falkowskiego. Zgodnie z nią wizerunek jest szczególnego rodzaju wyobrażeniem, które jest tworzone w określonym celu, na przykład wyborczym ${ }^{11}$. Użycie określenia „wyobrażenie” implikuje subiektywny charakter wizerunku, co oznacza, że powstaje on w umyśle odbiorcy. Akt tworzenia odbywa się zatem „w zaciszu” umysłu, „jest sumą informacji różnego rodzaju łączonych (»konstruowanych «) przez ludzki umysł w znaczącą całość" 12 .

Subiektywny charakter procesu poznawczego nie wyklucza jednak oddziaływania czynników zewnętrznych na podmiot konstytuujący opinię. Dlatego też zarówno sam polityk, jak i osoby współtworzące jego wizerunek podejmują określone działania w celu uzyskania wpływu na sposób myślenia odbiorcy. Ich celem jest wywoływanie w umyśle tego ostatniego takich skojarzeń, które przydadzą obiektowi dodatkowych wartości, na przykład społeczno-psychologicznych, etycznych czy osobowościowych ${ }^{13}$. Proces ten warunkowany jest emocjonalnie. Należy przy tym zauważyć, że osobowość kandydata i jego kompetencje wykreowane na potrzeby marketingu mogą się bardzo różnić od oryginału - jest to tak zwany efekt Ottingera ${ }^{14}$.

Wizerunek osoby publicznej kształtują zarówno komponenty szeroko pojmowanej komunikacji niewerbalnej, takie jak mimika, gesty, sposób poruszania się, wygląd zewnętrzny, kontekst sytuacyjny, czasowy, przestrzenny, jak i akty komunikacji werbalnej. Badacze wizerunku, jak zauważa Marek Kochan, więcej uwagi poświęcają zachowaniom niewerbalnym, co można uzasadnić tym, że właśnie tego typu komunikacja mocniej oddziałuje emocjonalnie na odbiorcę i kształtuje jego opinię ${ }^{15}$. Nie można jednak bagatelizować znaczenia wpływu wypowiedzi na postrzeganie nadawcy. Kiedy ten wypowiada się na tematy bardziej złożone i to w warunkach stresu, trudniej mu kontrolować przekaz i utrzymać spójność wizerunku i rzeczywistości. Jak zauważa Kochan: „Czy przypadkiem wówczas właśnie zachowania werbalne nie będą tym, co trudniej kontrolować, a więc czy nie okażą się informacją bardziej wiarygodną i tym samym w większym stopniu kształtującą wizerunek w oczach odbiorców?"16. Podczas gdy aktor stara się uwiarygodnić swój wyidealizowany wizerunek, odbiorca dąży do oddzielenia prawdy od kreacji. Najbardziej wiarygodny jest ten polityk, którego wizerunek jest w opinii jego odbiorców spójny z rzeczywistością ${ }^{17}$.

11 W. Cwalina, A. Falkowski, Marketing polityczny. Perspektywa psychologiczna, Gdańsk 2005, s. 153.

12 K. Konecki, op. cit., s. 155.

13 Ibidem, s. 154.

14 Określenie „efekt Ottingera” pochodzi od nazwiska kandydata na senatora hrabstwa New York. Podczas kampanii przedstawiano go jako człowieka zdecydowanego i pełnego wigoru. W konfrontacji z innymi kandydatami okazał się natomiast powolny i niepewny. Por. M. Mazur, Marketing polityczny, Warszawa 2002, s. 84 .

15 M. Kochan, Językowy wymiar wizerunku osób publicznych, [w:] A. Budzyńska-Daca, A. Kampka, K. Molek-Kozakowska, Retoryka wizerunku medialnego, Warszawa 2016, s. 156-157.

16 Ibidem, s. 161.

17 Ibidem. 
$\mathrm{Na}$ językowy wizerunek osoby publicznej składają się wypowiedzi formułowane przez nią samą, lecz też przypisywane jej lub z nią łączone. W przeprowadzonym badaniu językowego wizerunku Roberta Biedronia wzięto pod uwagę jedynie te wymienione na pierwszym miejscu, to znaczy poddano analizie jego własne wypowiedzi. Badaniem, jak już wspomniano, objęto komunikaty ustne udostępnione w serwisie YouTube, które opublikowano $\mathrm{w}$ internecie $\mathrm{w}$ trakcie kampanii wyborczej tego kandydata na prezydenta miasta Słupsk. Wybrano zatem tylko jeden kanał informacyjny i to w wybranym okresie, co było uzasadnione $\mathrm{z}$ kilku powodów.

W badaniu przyjęto założenie, że na poglądy i postawy współczesnych Polaków, zwłaszcza młodzieży, najmocniej oddziałuje internet oraz forma nagrania audiowizualnego. Z internetu korzystają regularnie ponad dwie trzecie dorosłych Polaków ${ }^{18}$. Nagrania audiowizualne kształtują percepcję odbiorcy, gdyż oddziałują na dwa najważniejsze ludzkie zmysły, czyli wzrok i słuch ${ }^{19}$.

Ograniczenie czasowe nałożone na wybór materiałów do analizy wynikało z przyjęcia za umowną datę rozpoczęcia kampanii prezydenckiej Roberta Biedronia dnia 22 lipca 2014 roku. W tym dniu serwis Gryf24.pl opublikował artykuł zatytułowany R. Biedroń: Nie wykluczam kandydowania na fotel prezydenta Słupska. Można w nim było przeczytać między innymi, że Robert Biedroń, poseł Twojego Ruchu, zastanawia się nad startem w jesiennych wyborach samorządowych na stanowisko prezydenta Słupska. Przytoczono również słowa posła: „Na razie jednak nie podjąłem żadnej decyzji w tej sprawie. O tym, czy ostatecznie zdecyduję się kandydować na prezydenta Słupska, będzie wiadomo mniej więcej w połowie sierpnia" ${ }^{20}$. Ostatecznie decyzję o ubieganiu się o fotel prezydenta Słupska Biedroń ogłosił na początku września 2014 roku. Serwis Gryf24.pl opublikował nagranie, w którym kandydat powiadamia, że 2 września zarejestrowano Komitet Wyborczy Wyborców Roberta Biedronia ${ }^{21}$. Wszystkie analizowane materiały audiowizualne opublikowane w serwisie YouTube pochodzą z okresu między 2 września i 30 listopada 2014 roku. Badaniu poddano 18 nagrań o łącznym czasie trwania $183 \mathrm{mi}-$ nuty i 52 sekundy. W zebranym materiale znalazły się następujące formy wypowiedzi: występ na żywo, wywiad, spot wyborczy i wystąpienie w sejmie.

\section{Podsumowanie wyników badania}

Głównym tematem poruszanym przez Roberta Biedronia w analizowanych wypowiedziach jest jego program wyborczy. Przedstawia w nim cele, które zamierza zrealizować po objęciu urzędu, i sposoby ich realizacji, zapowiada styl wykonywania

18 Korzystanie $z$ Internetu, komunikat z badań CBOS nr 92/2016, http://www.cbos.pl/SPISKOM. POL/2016/K_092_16.pdf (dostęp: 1.09.2017).

19 M. Laskowska, Oddziaływanie i wpływ mediów audiowizualnych: zarys problematyki, „Studia Ełckie” 2012, nr 14, s. 351-352.

20 R. Biedroń: Nie wykluczam kandydowania na fotel prezydenta Stupska, 22.07.2014, http://gryf24. pl/2014/07/22/r-biedron-wykluczam-kandydowania-fotel-prezydenta-slupska/ (dostęp: 1.09.2017).

21 Robert Biedroń kandyduje na prezydenta Stupska, 2.09.2014, https://www.youtube.com/watch?v=TK43gvHh0lE (dostęp: 1.09.2017). 
obowiązków, podkreśla zalety swojej osoby i kandydatów ze swojego komitetu wyborczego. Odnosi się również do wartości i wspomina o swoim stanowisku wobec religii i Kościoła.

W tabeli 1 zestawiono chronologicznie wypowiedzi Biedronia z okresu kampanii wyborczej z uwzględnieniem podziału na formy. Zaznaczono w niej, do jakich kwestii odnosił się w wywiadach i jaką tematykę wybierał w wystąpieniach publicznych.

Tabela 1. Problematyka wypowiedzi Roberta Biedronia z okresu 2.09.-30.11.2014 opublikowanych w serwisie YouTube

\begin{tabular}{|c|c|c|c|}
\hline \multicolumn{4}{|c|}{ Występ na żywo } \\
\hline Data & Tytuł & Problematyka & Główne tematy \\
\hline 2.09 .2014 & $\begin{array}{l}\text { Robert Biedroń kandyduje } \\
\text { na prezydenta Stupska }\end{array}$ & $\begin{array}{l}\text { Kandydat prezentuje powo- } \\
\text { dy ubiegania się o mandat } \\
\text { prezydenta. Wykazuje błędy } \\
\text { dotychczasowego prezydenta } \\
\text { Słupska. }\end{array}$ & $\begin{array}{l}\text { Obietnice wyborcze, } \\
\text { krytyka urzędującego pre- } \\
\text { zydenta }\end{array}$ \\
\hline 6.10 .2014 & $\begin{array}{l}\text { Robert Biedroń przedsta- } \\
\text { wia liderów list do RM } \\
\text { Stupsk }\end{array}$ & $\begin{array}{l}\text { Kandydat przedstawia zalety } \\
\text { i podkreśla wysoki status spo- } \\
\text { łeczny kandydatów na radnych } \\
\text { miejskich swojego komitetu } \\
\text { wyborczego: wykładow- } \\
\text { ców i absolwentów znanych } \\
\text { uczelni, przedsiębiorców, } \\
\text { prawników, prezesa spółdziel- } \\
\text { ni mieszkaniowej, radnych. } \\
\text { Zaznacza ich prawość oraz } \\
\text { uczciwość. }\end{array}$ & $\begin{array}{l}\text { Zalety kandydatów wła- } \\
\text { snego komitetu wybor- } \\
\text { czego, wartości }\end{array}$ \\
\hline 18.11 .2014 & $\begin{array}{l}\text { Robert Biedroń, podsu- } \\
\text { mowanie pierwszej tury } \\
\text { wyborów }\end{array}$ & $\begin{array}{l}\text { Kandydat podkreśla zalety } \\
\text { członków komitetu wy- } \\
\text { borczego: niezależność od } \\
\text { partii, kierowanie się zasadą } \\
\text { oszczędności, działanie dla } \\
\text { dobra społeczności, od- } \\
\text { powiedzialność. Obiecuje } \\
\text { prowadzenie dialogu i współ- } \\
\text { pracę z przeciwnikami poli- } \\
\text { tycznymi po objęciu urzędu } \\
\text { oraz dopuszczenie mieszkan- } \\
\text { ców do współdecydowania } \\
\text { o mieście. Podkreśla koniecz- } \\
\text { ność i wolę przeprowadzenia } \\
\text { zmian. }\end{array}$ & $\begin{array}{l}\text { Zalety kandydatów ko- } \\
\text { mitetu wyborczego, spo- } \\
\text { sób sprawowania urzędu, } \\
\text { konieczność wprowadze- } \\
\text { nia zmian }\end{array}$ \\
\hline
\end{tabular}




\begin{tabular}{|c|c|c|c|}
\hline 24.11 .2014 & $\begin{array}{l}\text { Robert Biedroń zaprasza do } \\
\text { rozmów ponad podziałami }\end{array}$ & $\begin{array}{l}\text { Kandydat apeluje o współ- } \\
\text { pracę ponad podziałami } \\
\text { partyjnymi i politycznymi. } \\
\text { Podkreśla swoją niezależność } \\
\text { polityczną i obywatelską po- } \\
\text { stawę. }\end{array}$ & $\begin{array}{l}\text { Sposób sprawowania urzę- } \\
\text { du, zalety }\end{array}$ \\
\hline 30.11 .2014 & $\begin{array}{l}\text { Robert Biedroń prezyden- } \\
\text { tem Stupska }\end{array}$ & $\begin{array}{l}\text { Kandydat przypomina cele } \\
\text { polityczne i społeczne oraz } \\
\text { sposoby ich osiągnięcia. Po- } \\
\text { sługuje się znanymi z okresu } \\
\text { kampanii sloganami wybor- } \\
\text { czymi. }\end{array}$ & Program wyborczy \\
\hline \multicolumn{4}{|c|}{ Spot reklamowy } \\
\hline Data & Tytuł & Problematyka & Główne tematy \\
\hline 8.11 .2014 & $\begin{array}{l}\text { Robert Biedroń otwiera } \\
\text { „Stupską porodówkę" }\end{array}$ & $\begin{array}{l}\text { Kandydat apeluje o poparcie } \\
\text { i przypomina, że wybrano go } \\
\text { na najlepszego posła w sej- } \\
\text { mie. }\end{array}$ & Autopromocja \\
\hline 9.11 .2014 & $\begin{array}{l}\text { Kandydat na Prezydenta } \\
\text { Stupska Robert Biedroń- } \\
\text { „Nareszcie Zmiana” }\end{array}$ & $\begin{array}{l}\text { Kandydat składa obietnicę } \\
\text { wybudowania obiektów, } \\
\text { w których będą realizowane } \\
\text { życiowe potrzeby mieszkań- } \\
\text { ców: oddział położniczy, } \\
\text { centrum geriatrii, instytut } \\
\text { zielonych technologii. }\end{array}$ & Obietnice wyborcze \\
\hline
\end{tabular}

Wywiad

\begin{tabular}{c|l|l|l}
\hline Data & \multicolumn{1}{|c|}{ Tytuł } & \multicolumn{1}{c}{ Problematyka } & \multicolumn{1}{c}{ Główne tematy } \\
\hline \multirow{2}{*}{ 26.09.2014 } & $\begin{array}{l}\text { Biedroń i Gawkowski } \\
\text { o wspólnym lewicowym } \\
\text { kandydacie na prezyden- } \\
\text { ta RP }\end{array}$ & $\begin{array}{l}\text { Kandydat mówi o warto- } \\
\text { ściach Twojego Ruchu, zale- } \\
\text { tach i dokonaniach tej partii. } \\
\text { Podkreśla osobistą obywatel- } \\
\text { ską postawę. }\end{array}$ & Autopromocja \\
\hline \multirow{3}{*}{18.10 .2014} & $\begin{array}{l}\text { Robert Biedroń, kandydat } \\
\text { na prezydenta Stupska }\end{array}$ & $\begin{array}{l}\text { Kandydat krytykuje spo- } \\
\text { sób zarządzania miastem. } \\
\text { Wskazuje na zaniedbania } \\
\text { dotychczasowego prezyden- } \\
\text { ta. Składa obietnicę prze- } \\
\text { prowadzenia określonych } \\
\text { zmian w polityce miejskiej } \\
\text { i wskazuje sposoby realizacji } \\
\text { zadań. }\end{array}$ & $\begin{array}{l}\text { Krytyka urzędującego } \\
\text { prezydenta, obietnice } \\
\text { wyborcze }\end{array}$ \\
\hline
\end{tabular}




\begin{tabular}{|c|c|c|c|}
\hline 31.10 .2014 & $\begin{array}{l}\text { Tu kandyduje, bo tu „czu- } \\
\text { je się jak } w \text { domu”. Robert } \\
\text { Biedroń chce rządzić } \\
\text { Stupskiem }\end{array}$ & $\begin{array}{l}\text { Kandydat zapowiada mene- } \\
\text { dżerski sposób zarządzania } \\
\text { miastem, współpracę z miesz- } \\
\text { kańcami. Obiecuje, że będzie } \\
\text { żyć równie skromnie jak } \\
\text { mieszkańcy. }\end{array}$ & $\begin{array}{l}\text { Sposób sprawowania } \\
\text { urzędu }\end{array}$ \\
\hline 5.11 .2014 & $\begin{array}{l}\text { Biedroń: żyjemy w hetero- } \\
\text { matriksie. „Kiedy geje ła- } \\
\text { pia się za ręke, to od razu } \\
\text { jest prowokacja” }\end{array}$ & $\begin{array}{l}\text { Kandydat prezentuje swoje } \\
\text { stanowisko odnośnie do } \\
\text { homoseksualizmu. Apeluje } \\
\text { o poszanowanie różnorod- } \\
\text { ności. Zaznacza swoje sta- } \\
\text { nowisko co do oddzielenia } \\
\text { spraw Kościoła od spraw } \\
\text { państwa. }\end{array}$ & $\begin{array}{l}\text { Wartości, stanowisko } \\
\text { wobec Kościoła }\end{array}$ \\
\hline 7.11 .2014 & $\begin{array}{l}\text { Biedroń do Wiplera: nie bądź } \\
\text { mamą Madzi }\end{array}$ & $\begin{array}{l}\text { Kandydat krytykuje zacho- } \\
\text { wanie Przemysława Wiplera, } \\
\text { zarzuca mu zachowania nie- } \\
\text { zgodne z głoszonymi zasa- } \\
\text { dami, manipulowanie opinią } \\
\text { publiczną, wykorzystanie } \\
\text { głośnej w mediach sprawy } \\
\text { do zajmowania własną osobą } \\
\text { opinii publicznej. Zarzuca } \\
\text { polskiej policji nieprofesjo- } \\
\text { nalne zachowanie, „kolesio- } \\
\text { stwo”. }\end{array}$ & $\begin{array}{l}\text { Wartości, krytyka służb } \\
\text { publicznych }\end{array}$ \\
\hline 22.11 .2017 & $\begin{array}{l}\text { Robert Biedroń walczy } \\
\text { o Stupsk. „Synu, czy } \\
\text { będziesz atakowat Ko- } \\
\text { ściót?” }\end{array}$ & $\begin{array}{l}\text { Kandydat przedstawia swój } \\
\text { sposób pozyskiwania zwo- } \\
\text { lenników podczas kampanii } \\
\text { wyborczej. }\end{array}$ & Autopromocja \\
\hline 24.11 .2014 & $\begin{array}{l}\text { Wywiad z Robertem Bie- } \\
\text { droniem }\end{array}$ & $\begin{array}{l}\text { Kandydat przedstawia wizję } \\
\text { rozwoju miasta i sposób } \\
\text { sprawowania prezydentury. } \\
\text { Podkreśla apolityczność } \\
\text { i obywatelski charakter ko- } \\
\text { mitetu wyborczego, a także } \\
\text { swoją niezależność polityczną. } \\
\text { Omawia konieczne obszary } \\
\text { zmian w mieście, a także } \\
\text { sposoby osiągania tych celów. } \\
\text { Zaznacza wierność zasadzie } \\
\text { odrębności władzy politycznej } \\
\text { od Kościoła. Podkreśla, że nie } \\
\text { zamierza kontynuować dzia- } \\
\text { łalności na rzecz środowiska } \\
\text { LGBT po wygraniu wyborów. }\end{array}$ & $\begin{array}{l}\text { Sposób sprawowania } \\
\text { urzędu, obietnice wybor- } \\
\text { cze, stanowisko wobec } \\
\text { Kościoła }\end{array}$ \\
\hline
\end{tabular}




\begin{tabular}{|c|c|c|c|}
\hline \multicolumn{4}{|c|}{ Wystąpienie w sejmie } \\
\hline Data & Tytuł & Problematyka & Główne tematy \\
\hline 25.09.2014 & $\begin{array}{l}\text { Wystąienie posta Biedronia } \\
\text { w sprawie prześladowań } \\
\text { w Syrii i Iraku }\end{array}$ & $\begin{array}{l}\text { Uzasadnienie decyzji wstrzy- } \\
\text { mania się przez Twój Ruch od } \\
\text { poparcia poselskiego projektu } \\
\text { uchwały w sprawie ludobój- } \\
\text { stwa dokonywanego na chrze- } \\
\text { ścijanach, Azjatach i Kurdach } \\
\text { oraz innych mniejszościach } \\
\text { religijnych i etnicznych przez } \\
\text { organizację terrorystyczną } \\
\text { „Państwo Islamskie” na obsza- } \\
\text { rze północnego Iraku i Syrii. } \\
\text { Krytykuje zawarty w projekcie } \\
\text { podział ludności na religie } \\
\text { gorsze i lepsze. Wskazuje na } \\
\text { brak realizacji uchwał, które } \\
\text { mają pomóc w rozwiązaniu } \\
\text { konfliktu w Syrii. }\end{array}$ & Wartości \\
\hline 26.09.2014 & $\begin{array}{l}\text { Robert Biedroń - wysta- } \\
\text { pienie z } 24 \text { września } 2014 \\
\text { roku }\end{array}$ & $\begin{array}{l}\text { Krytyka stanowiska rządu od- } \\
\text { nośnie do odmowy ratyfikacji } \\
\text { Konwencji Europy o zapobie- } \\
\text { ganiu i zwalczaniu przemocy } \\
\text { wobec kobiet i przemocy do- } \\
\text { mowej. Prezentacja stanowi- } \\
\text { ska Klubu Poselskiego Twój } \\
\text { Ruch w tej sprawie. Robert } \\
\text { Biedroń apeluje o poparcie tej } \\
\text { konwencji. }\end{array}$ & Wartości \\
\hline
\end{tabular}

Źródło: opracowanie własne.

Zebrany materiał poddano kodowaniu, podczas którego danym przypisano etykiety, wydobywając $\mathrm{w}$ ten sposób dużą ich liczbę. Po otwartym zakodowaniu wypowiedzi konieczne było podjęcie decyzji, które kategorie poddać dalszej analizie. W tym celu przeprowadzono badanie ilościowe, wychodząc z założenia, że statystyczna dominacja określonych znaków językowych „wdrukuje” w umysł odbiorcy pożądany schemat myślenia o danym obiekcie. Wielokrotne powtarzanie tego samego wyrazu, lecz także innych znaków językowych skupionych w jego polu semantycznym (skojarzeń) jest jedną $\mathrm{z}$ technik perswazji stosowanych z powodzeniem między innymi w reklamie.

Zastosowanie techniki ilościowej w badaniu pozwoliło na wytypowanie następujących słów używanych najczęściej przez Roberta Biedronia: współpraca/współdecydowanie, dialog/dyskusja/debata, różne środowiska/różnorodność, niezależność/spoza układu, bezpartyjność/apolityczność, przyjazne państwo/miasto, otwarte miasto, drużyna, doświadczenie, zarządzanie, budować, robić porządek/posprzątać, skromność, pokora, wizja/przyszłość, zmiana, nowoczesność/innowacyjność, ekologia. Nadano im następujące kategorie: podmiotowość, demokrata, menedżer, dobra zmiana, wizjoner. 
Akcentowanie współpracy, współdecydowania, dialogu wyraża przywiązanie kandydata do idei podmiotowości obywateli. Podkreślają to takie wyrażenia, jak „rozmawia się z ludźmi”22, „trzeba słuchać ludzi”23, „miasto otwarte na obywateli”24 czy „podejmiemy wspólnie razem decyzję"25. Różnorodność poglądów i postaw obywateli nie stoi na przeszkodzie ich integracji, o czym świadczy umieszczanie wyrazu „różnorodność” i jego znaczeniowych odpowiedników w wypowiedziach nacechowanych pozytywnie. Kandydat dąży do integrowania obywateli, czemu ma służyć apolityczność urzędu. Apeluje do potencjalnych wyborców: „Słupsk zasługuje na to, żebyśmy usiedli do stołu ponad podziałami”26.

Wizerunek demokraty uzupełniają cechy menedżera. Najważniejszym zadaniem prezydenta-menedżera jest „zarządzanie, a nie rządzenie miastem”27. Biedroń ceni sobie kompetencje i doświadczenie, a pośród cech osobistych ważne są dla niego skromność i pokora.

Podczas kampanii wyborczej Biedroń wielokrotnie używa określenia „dobra zmiana”, które kojarzy z wizją uporządkowanego, nowoczesnego miasta. Prezydent-wizjoner, według którego miastu potrzebny jest „dobry menedżer, który uzdrowi firmę”, zamierza „budować”, „robić porządek” i „posprzątać” oraz wprowadzić „nowoczesne rozwiązania”28.

Interesujące wnioski można wysnuć z zestawienia częstotliwości stosowania wyrazów w liczbie pojedynczej ze słowami wypowiedzianymi w liczbie mnogiej (czasowniki i zaimki). Poszukiwanie opozycji między „ja” a „my” służyło wskazaniu, czy kandydat ma skłonność do podkreślania swojej sprawczej roli, czy też akcentuje służebny charakter urzędu prezydenta. Analiza częstotliwości używania czasowników i zaimków wskazujących na podmiot działania — „ja” w opozycji do „my” - wykazała znaczną, gdyż ponad trzykrotną, przewagę tej pierwszej opcji. Taki zabieg umożliwia wyeksponowanie takich cech kandydata, jak stanowczość, asertywność, a także umiejętność podejmowania decyzji.

\section{Podsumowanie}

Badanie zachowań językowych Roberta Biedronia budujących jego wizerunek podczas kampanii wyborczej w 2014 roku można podsumować stwierdzeniem, że kandydat najczęściej używał znaków językowych skupionych w polach semantycznych wokół słów podstawowych: demokrata i menedżer. Kandydat dostrzega i ceni podmiotowość miesz-

22 Robert Biedroń walczy o Słupsk. „Synu, czy będziesz atakował Kościół?”, 22.11.2014, http://trojmiasto.wyborcza.pl/trojmiasto/1,35612,17008940,Robert_Biedron_walczy_o_Slupsk__Synu_czy_bedziesz. html? disableRedirects=true (dostęp: 1.09 .2017$)$.

23 Ibidem.

24 Robert Biedroń kandyduje...

25 Wywiad $z$ Robertem Biedroniem, 24.11.2014, https://www.youtube.com/watch?v=wxeldSoRC8k (dostęp: 1.09.2017).

26 Robert Biedroń prezydentem Słupska, 30.11.2014, https://www.youtube.com/watch?v=1MdzGMyRz8c (dostęp: 1.09.2017).

27 Wywiad...

28 Ibidem. 
kańców, pragnie ich zaangażować w działania na rzecz wspólnego dobra, zachęca do dzielenia się opiniami i pomysłami. Taka prezydentura najbliższa jest demokratycznemu stylowi zarządzania, którego charakterystycznymi cechami jest utrzymywanie więzi z mieszkańcami, dążenie do uzyskania ich aprobaty, a także wysłuchiwanie, zachęcanie do wyrażania opinii oraz konsultowanie pomysłów. Menedżer, który zapowiada demokratyczny styl prezydentury, ceni sobie podmiotowość mieszkańców i przyznaje im prawo do współdecydowania, nie może więc odznaczać się pychą i arogancją. Dlatego cechami osobistymi, których przejawianie podkreśla Robert Biedroń, są skromność i pokora. Menedżer i demokrata jest również wizjonerem. Fundamentem zapowiadanej dobrej zmiany ma być zarówno opisana już obywatelskość, jak i nowoczesność.

Miarą popularności proponowanego przez Biedronia stylu prezydentury i modelu wartości jest zwycięstwo tego kandydata w wyborach samorządowych. Zwykle w tego typu wyborach bezpośrednich wygrywają urzędujący kandydaci. O tym, czy zapowiadany styl zarządzania miastem był realizowany i czy spełnił potrzeby mieszkańców, można byłoby się przekonać podczas kolejnych wyborów samorządowych, w których Robert Biedroń ponownie ubiegałby się o stanowisko prezydenta miasta.

\section{Bibliografia}

Biedroń do Wiplera: nie bądź „mama Madzi”, 7.11.2014, http://www.tvp.info/17563709/biedron-do-wiplera-nie-badz-mama-madzi (dostęp: 1.09.2017).

Biedroń i Gawkowski o wspólnym lewicowym kandydacie na prezydenta RP, 26.09.2014, https://www. youtube.com/watch?v=c3-yLg_X7Pk (dostęp: 1.09.2017).

Biedroń: żyjemy w heteromatriksie. „Kiedy geje łapia się za rękę, to od razu jest prowokacja”, 5.11.2014, http://www.tvn24.pl/kropka-nad-i,3,m/biedron-zyjemy-w-heteromatriksie-kiedy-geje-lapia-sie-zareke-to-od-razu-jest-prowokacja,485469.html (dostęp: 1.09.2017).

Cwalina W., Falkowski A., Marketing polityczny. Perspektywa psychologiczna, GWP Gdańskie Wydawnictwo Psychologiczne, Gdańsk 2005.

Kandydat na Prezydenta Stupska Robert Biedroń - „Nareszcie Zmiana” - Komitet Wyborczy Wyborców Roberta Biedronia NARESZCIE ZMIANA!, 9.11.2014, https://www.youtube.com/watch?v=4j7OHaQ8jB8 (dostęp: 1.09.2017).

Kochan M., Językowy wymiar wizerunku osób publicznych, [w:] A. Budzyńska-Daca, A. Kampka, K. Molek-Kozakowska, Retoryka wizerunku medialnego, Polskie Towarzystwo Retoryczne, Warszawa 2016, s. $153-189$.

Konecki K., Studia z metodologii badań jakościowych. Teoria ugruntowana, Wydawnictwo Naukowe PWN, Warszawa 2000.

Korzystanie z Internetu, komunikat z badań CBOS nr 92/2016, http://www.cbos.pl/SPISKOM.POL/2016/K_092_16.PDF (dostęp: 1.09.2017).

Kostera M., Antropologia organizacji. Metodologia badań terenowych, Wydawnictwo Naukowe PWN, Warszawa 2005.

Laskowska M., Oddziaływanie i wplyw mediów audiowizualnych: zarys problematyki, „Studia Ełckie” 2012, nr 14, s. 351-360.

Mazur M., Marketing polityczny, Wydawnictwo Naukowe PWN, Warszawa 2002. 
R. Biedroń: Nie wykluczam kandydowania na fotel prezydenta Stupska, 22.07.2014, http://gryf24.pl/2014/07/22/r-biedron-wykluczam-kandydowania-fotel-prezydenta-slupska/ (dostęp: 1.09.2017).

Robert Biedroń - wystapienie z 24 września 2014 r., 26.09.2014, https://www.youtube.com/watch?v=SpQvBTsQCrc (dostęp: 1.09.2017).

Robert Biedroń, kandydat na prezydenta Stupska - Głosuję świadomie, 18.10.2014, https://www.youtube. com/watch?v=5AjQ1oS713I (dostęp: 1.09.2017).

Robert Biedroń kandyduje na prezydenta Stupska, 2.09.2014, https://www.youtube.com/watch?v=TK43gvHh0lE (dostęp: 1.09.2017).

Robert Biedroń otwiera „Stupską porodówkę”, 24.08.2014, https://www.youtube.com/watch?v=z_IBSwMbi-4 (dostęp: 1.09.2017).

Robert Biedroń, podsumowanie pierwszej tury wyborów, 18.11.2014, https://www.youtube.com/watch?v=SK7JRvoxAZI (dostęp: 1.09.2017).

Robert Biedroń prezydentem Stupska, 30.11.2014, https://www.youtube.com/watch?v=1MdzGMyRz8c (dostęp: 1.09.2017).

Robert Biedroń przedstawia liderów list do Rady Miejskiej w Słupsku, 6.10.2014, https://www.youtube.com/ watch? $\mathrm{v}=\mathrm{Bd} 1 \mathrm{cQJkNy}$ _E (dostęp: 1.09.2017).

Robert Biedroń walczy o Stupsk. „Synu, czy będziesz atakował Kościót?”, 22.11.2014, http://trojmiasto.wyborcza.pl/trojmiasto/1,35612,17008940,Robert_Biedron_walczy_o_Slupsk__Synu_czy_bedziesz. html?disableRedirects=true (dostęp: 1.09.2017).

Robert Biedroń zaprasza do rozmów ponad podziałami, 24.11.2014, https://www.youtube.com/watch?v=CR1H17dOH9g (dostęp: 1.09.2017).

Strauss A.L., Qualitative Analysis for Social Scientists, Cambridge University Press, Cambridge 1987.

Szczudlińska-Kanoś A., Marketing polityczny w polskim samorządzie regionalnym, „Studia Regionalne i Lokalne" 2009, nr 3, s. 105-119.

Tu kandyduje, bo tu „czuje się jak w domu”. Robert Biedroń chce rządzić Stupskiem, 31.10.2014, http:// www.tvn24.pl/pomorze,42/tu-kandyduje-bo-tu-czuje-sie-jak-w-domu-robert-biedron-chce-rzadzicslupskiem,482120.html (dostęp: 1.09.2017).

Wiadomości Stupsk - 24.11.2014 - 10 minut TV, 24.11.2014, https://www.youtube.com/watch?v=SdXjIkHk95E (dostęp: 1.09.2017).

Wystapienie posła Biedronia w sprawie prześladowań w Syrii i Iraku, 25.09.2014, https://www.youtube.com/ watch?v=sQ122jbeYok (dostęp: 1.09.2017).

Wywiad z Robertem Biedroniem, 24.11.2014, https://www.youtube.com/watch?v=wxeldSoRC8k (dostęp: 1.09.2017).

\section{Public personality image management: Self-creation of Robert Biedroń during the mayoral campaign in 2014}

Keywords: personal branding, self-image, political marketing, electoral campaign, social media

Summary

A key element of each electoral campaign is to create an image of the candidate corresponding to the voters' expectations. This is an essential task when the vast majority of voters declares that the candidate's personality was decisive for their voting decisions. An image is a specific construct composed of information provided to the recipient by the candidates themselves, by their staff and mass media, as well as the voters' personal reflections. The paper focuses on the verbal behaviour of Robert Biedron in the time when he was running for town mayor of Słupsk in the 2014 elections. This set of major features creates a specific image of the candidate which could have affected the result of the elections in 2014. 